\title{
RELASI ANTARMANUSIA \\ DALAM NILAI-NILAI BUDAYA BUGIS: PERSPEKTIF FILSAFAT DIALOGIS MARTIN BUBER
}

\section{Muhammad Hadis Badewi}

STIE Muhammadiyah, Palopo, Sulawesi Selatan

Email: emhadis@yahoo.co.id

\begin{abstract}
Abstrak
Artikel ini ingin mengungkap fenomena kearifan lokal tentang relasi antarmanusia pada masyarakat Bugis yang terdapat dalam kitab La Galigo. Artikel ini bertujuan untuk menjelaskan konsep relasi antarmanusia yang terdapat dalam nilai-nilai budaya Bugis dan relevansinya dengan pembangunan Hak Asasi Manusia di Indonesia. Filsafat dialogis Martin Buber, yang menguraikan tentang relasi antarmanusia, digunakan sebagai sebuah perspektif dalam artikel ini. Ada tiga bentuk relasi yang terdapat dalam pemikiran Buber, I-It, I - Thou, dan I-Eternal Thou. Berbicara tentang relasi antarmanusia, dalam kearifan lokal masyarakat Bugis, nilai-nilai semacam itu telah lama dimiliki dan dipahami dalam bentuk konsepsi budaya. Konsep relasi sipakasiri' dipahami sebagai konsep relasi yang tabu, konsep relasi sipassiriki dianggap sebagai konsep ideal dalam membangun relasi antarmanusia, yang kemudian memuncak pada konsep mappesona ri dewata seuwwae. Berdasarkan konsep-konsep tersebut, bisa dikatakan bahwa kajian relasi antarmanusia yang terdapat dalam nilai-nilai budaya Bugis, memiliki relevansi yang kuat dengan upaya pembangunan Hak Asasi Manusia di Indonesia.
\end{abstract}

Kata kunci: kearifan lokal, Bugis, relasi antarmanusia, Martin Buber, hak asasi manusia.

\section{Abstract}

This article analyzes the local wisdom of Bugisnese that guide the relationship among human which is highlighted in the Bugis ancient book, La Galigo. This article aims to explain concepts of the human relationship in the cultural values of Bugisnese and its relevance to the human rights development in Indonesia. Using Martin Buber's philosophical perspective, this article adopts three types of relationship known as I-It, I-Thou and I-Eternal Thou. In Bugisnese context, Buber's perspectives have been adopted and understood into the cultural concept/values for a long time. They practiced sipakasiri' which highlights a taboo relationship. They believed in sipassiriki as an ideal concept in human being relationship and contended that mappesona ri dewata seuwwae is the most crucial concept that exist among them. These shared Bugisnese values are 
relevant to the development of human rights in Indonesia.

Keywords: local wisdom, Bugisnesse, human relationship, Martin Buber, human rights.

\section{PENDAHULUAN}

Setiap periode sejarah manusia memiliki corak perkembangan pemikiran dan filosofi hidup yang berbeda-beda yang dikembangkan secara turun-temurun, termasuk bagaimana manusia membangun konsep hubungan antarsesama. Konsep hubungan antarmanusia yang tumbuh di setiap kelompok masyarakat memiliki corak yang berbeda pula, karena manusia memiliki banyak kearifan yang kaya dengan perbedaan. Banyaknya konsep yang muncul akan menambah pemahaman manusia tentang bagaimana membangun hubungan antarsesama, demi sebuah hubungan yang lebih berkualitas.

Dunia modern yang merupakan simbol majunya pemikiran manusia dewasa ini, seharusnya menjadi tonggak kemanusiaan dalam membangun relasi yang jauh lebih baik, namun hal tersebut justru sangat jauh dari harapan jika melihat kondisi kemanusiaan yang hadir di tengah masyarakat modern, masyarakat yang memiliki pemikiran yang jauh lebih maju dari masyarakat yang hidup di era pra-modern. Telah tercatat dalam lembaran sejarah bahwa kondisi hubungan antarmanusia di jaman modern justru tidak jauh lebih baik dari jaman sebelumnya. Walaupun tak dapat dipungkiri bahwa dunia modern juga tetap memiliki sisi positifnya dalam hal tersebut.

Kondisi kemanusiaan dewasa ini tidak henti-hentinya dirundung prahara. Hal ini terjadi pada kelompok-kelompok masyarakat yang hidup terisolir di pedalaman terpencil, namun kenyataan ini sangat paradoksal. Hal itu justru lebih banyak terjadi pada masyarakat yang mengklaim diri sebagai masyarakat yang memiliki peradaban tinggi, masyarakat yang berperadaban modern, dan masyarakat yang beragama.

Ketika sebuah peradaban mengklaim diri sebagai peradaban yang tinggi, kemudian prahara kemanusiaan tidak henti-hentinya dipertontonkan, tentunya akan menimbulkan pertanyaan, di mana letak 
ketinggian peradaban tersebut? Masihkah layak dikatakan sebagai sebuah peradaban jika yang terjadi adalah ketidakberadaban, saling meniadakan, saling mengobjektifikasi. Arnold Toynbee mungkin tidak sepenuhnya keliru ketika mengatakan bahwa peradaban tidak pernah menjadi sebuah fakta.

"Para anggota masyarakat-masyarakat jenis ini menyebut dirinya "beradab" sampai jaman kita sekarang, ketika pengalaman kita yang mengerikan dan memalukan atas kekejaman-kekejaman manusia telah mengajarkan kepada kita bahwa keberadaban tidak pernah menjadi sebuah fakta yang sungguh-sungguh terjadi, namun hanyalah suatu upaya atau cita-cita yang, hingga kini, selalu jauh dari sasarannya yang ambisius"' (Toynbee, 2004:37).

Hal yang dikatakan oleh Toynbee tersebut adalah sebuah fakta sejarah atas tindakan manusia terhadap manusia lain yang saling meniadakan, namun bukan berarti peradaban yang hidup di dunia ini tidak lagi memiliki pandangan yang luhur terhadap eksistensi manusia. Sekecil apapun itu tetaplah sebuah pandangan yang sangat luhur. Kebudayaan yang pernah hidup dan yang masih hidup hingga saat ini masing-masing memiliki kearifan luhur. Entah itu masyarakat yang tergolong sebagai masyarakat yang masih berpola pikir tradisional maupun masyarakat yang pola pikirnya sudah sangat maju dan modern.

Setiap kebudayaan di dunia memiliki pandangannya masingmasing tentang manusia: bagaimana manusia hadir, bagaimana manusia membangun relasinya, bagaimana manusia berpengetahuan, bagaimana manusia berperilaku, dan tentunya masih banyak lagi pandangan tentang manusia yang tersebar dalam alam pemikiran di setiap kebudayaan yang telah hadir di sepanjang sejarah kehidupan dunia. Pandangan tentang manusia boleh dikatakan sebagai pandangan yang universal, pandangan yang terdapat di setiap kebudayaan. Namun itu bukan berarti bahwa pandangan-pandangan tersebut tidak memiliki perbedaan dan ciri khas masing-masing. Setiap kebudayaan memiliki ciri khasnya masing-masing dalam memandang manusia. 
Perbedaan pandangan tentang manusia yang terdapat pada setiap kebudayaan merupakan sebuah keunikan. Perbedaan, bukan berarti harus terjadi konflik di antara yang berbeda, tetapi justru harus membangun sebuah komunikasi, dan membangun sebuah relasi di antara keunikan-keunikan yang terjadi. Berbeda itu unik dan tidak harus mencari keseragaman, karena dengan adanya perbedaan akan terbangun perspektif baru.

Manusia tidak ada yang memiliki kesamaan yang persis antara satu dengan lainnya walaupun jumlah manusia di dunia ini setiap detiknya mengalami pertumbuhan yang semakin banyak. Tidak ada satu pun yang sama persis baik fisik, sikap, sifat, karakter, perilaku maupun mentalnya. Tidak ada satu pun di antara miliaran jumlah manusia di dunia ini yang persis sama dengan yang lainnya. Hal itu karena setiap manusia dilahirkan dengan keunikannya masing-masing, atau lahir dengan perbedaannya dengan manusia yang lain.

Salah satu persoalan sangat mendasar yang tidak terelakkan akan timbul jika ingin membicarakan manusia, yaitu pertanyaan mengapa manusia dikatakan sebagai manusia? Kadang untuk menjelaskan tentang manusia, itu harus berangkat dari persoalan mendasar tersebut. Ketika mencoba menjelaskan manusia berarti mencoba untuk merefleksikan diri sendiri, memikirkan dan mengidentifikasi diri sendiri sebagai manusia.

Kemampuan memikirkan dan mengidentifikasi diri merupakan salah satu keunikan yang terdapat pada manusia. Selain itu, manusia juga dianggap sebagai makhluk yang memiliki ciri spiritual-intelektual. Secara intrinsik ciri ini bersifat independen terhadap segala sesuatu yang bersifat material (Dagun, 1990: 8). Manusia memiliki keunikannya maka manusia dikatakan manusia. Manusia tidak bisa disamakan dengan makhluk hidup lainnya yang hanya hidup tanpa kesadaran.

"Manusia bicara tentang diri sendiri. Dalam bicara ini dia berkata tentang jiwa dan badan. Dasarnya: karena dia menangkap aspek rohani dan jasmani pada dirinya atau akunya. Selanjutnya jiwa dipandang sebagai sesuatu yang berdiri sendiri (di dalam) dan badan juga, tetapi kelihatan. 
Pikiran tentang badan dan jiwa ini salah. Untuk membenarkan, katakanlah: aku ini ya rohani ya jasmani. Badan adalah bentuk konkrit dari kejasmanianku, atau daripadaku sepanjang aku ini jasmani. Yang ada bukan badan, yang ada ialah aku ini dan badan adalah aku dalam bentukku jasmani. Badan adalah aku sendiri dalam kedudukanku sebagai makhluk jasmani, badan adalah wujudku sebagai makhluk jasmani" (Drijarkara, 1989: 12).

Bersama keunikan-keunikan yang ada padanya, manusia kemudian mengungkapkan dirinya dalam dunia material. Manusia beraktivitas dalam dunia material dengan membangun interaksi dengan lingkungannya, dengan sesama makhluk hidup, dan yang lebih khusus lagi adalah interaksi dengan sesama manusia.

Manusia dalam dunia material kemudian membangun relasi. Relasi dalam artian bahwa manusia dengan sesamanya membangun hubungan-hubungan baik yang saling menghargai, saling mencintai, bukan hubungan yang berbentuk saling meniadakan. Relasi antarmanusia tersebut tidak mengenal hal yang dinamakan objek, yang ada adalah subjek. Jadi dalam konsep relasi antarmanusia tidak mengenal adanya objek, manusia itu adalah subjek. Manusia tidak dapat dibendakan atau diobjektifikasi.

"Hubungan manusia dengan manusia bukan menambahkan sesuatu yang serba baru pada pengertian dan penghendakan 'biasa'. Komunikasi antarmanusiawi tidak berbeda secara mutlak dari segala macam korelasi 'normal'. Sebaliknya, justru hubungan subjek dengan partner sebagai subjek lain merupakan penghayatan optimal dari struktur komunikasi-partisipasi hakiki" (Bakker, 2008: 257).

Masyarakat Bugis adalah salah satu kelompok masyarakat yang hidup di Nusantara, yang memiliki pandangan tentang eksistensi manusia. Eksistensi manusia yang hidup dalam ranah kebudayaan Bugis tentunya memiliki ciri khas yang membedakannya dengan pan- 
dangan yang hidup dalam kebudayaan-kebudayaan lainnya. Bugis menjadi sebuah identitas bagi mayoritas masyarakat yang mendiami wilayah Sulawesi bagian Selatan yang telah berabad-abad membangun kebudayaannya.

Kearifan-kearifan yang terdapat dalam kebudayaan Bugis merupakan salah satu kekayaan kemanusiaan yang ada di dunia ini, khususnya di Indonesia. Kearifan-kearifan tersebut telah diwariskan secara turun-temurun, baik melalui tradisi lisan maupun tulisan yang telah lama dikenal oleh masyarakat Bugis dalam bentuk folklore.

Bersumber dari tradisi lisan dan tulisan itu masyarakat Bugis mengembangkan budayanya. Pengembangan budaya itu tidak hanya menghasilkan teknologi tetapi juga memikirkan tentang adanya manusia sebagai pribadi.

Alam kebudayaan masyarakat Bugis tersebut telah banyak ditemukan catatan budaya dan cerita rakyat yang mengungkapkan tentang manusia dan bagaimana seharusnya manusia menjalani kehidupannya. Kitab epos La Galigo merupakan salah satu rujukan tertulis nilainilai budaya yang hidup dan berkembang di tengah masyarakat Bugis. Epos tersebut telah memberikan gambaran tentang masa lampau orang Bugis.

“Orang Bugis sendiri mengenal masa lampau mereka melalui dua macam manuskrip anonim yang secara berturutturut dapat disebut sebagai mitos/epos dan teks sejarah/kronik. Jenis pertama berwujud sebuah karya sastra besar berisi cerita bersyair, yang dinamakan Sure' Galigo oleh orang Bugis, sesuai nama salah seorang tokoh utama cerita tersebut, yakni La Galigo. Jenis kedua, ... , adalah sejumlah besar kronik orang Bugis, Makassar, dan Mandar" (Pelras, 2003: 33).

Nilai-nilai kebudayaan Bugis dalam kitab epos La Galigo sangat banyak digambarkan. Penggambaran manusia Bugis dapat dilihat secara antropologis, sosiologis, maupun psikologis dari epos panjang itu. Selain dari kitab La Galigo, konstruksi kebudayaan yang hidup di tengah-tengah masyarakat Bugis juga banyak dihasilkan dari pemikir- 
an para cerdik-cendekia atau pemikir-pemikir Bugis di masa silam, di antaranya adalah To Ciung Maccae ri Luwu, La Pagala Nenek Mallomo, Kajaolaliddo, La Waniaga Arung Bila dan masih banyak lagi pemikir lainnya yang sejaman dengan mereka.

Berdasarkan latar belakang yang diuraikan di atas, maka persoalan atau masalah yang akan diajukan sebagai pijakan awal dalam penelitian ini adalah: (1) Apa hakikat manusia dalam pandangan budaya Bugis ditinjau dari perspektif filsafat dialogis Martin Buber?; (2) Apa makna konsep relasi antarmanusia dalam budaya Bugis?; dan (3) Bagaimana relevansi kajian relasi antarmanusia dengan pembangunan Hak Azasi Manusia (HAM) di Indonesia?

\section{FILSAFAT DIALOGIS MARTIN BUBER}

Konsep relasi antarmanusia yang berkembang dalam filsafat manusia, khususnya pada aliran eksistensialisme, dikembangkan oleh Martin Buber dan Gabriel Marcel, dua orang pemikir besar dalam aliran eksistensialisme. Keduanya dikenal dengan eksistensialis religius. Kedua tokoh ini memiliki dasar pemikiran yang tidak jauh berbeda dalam memandang manusia. Keduanya berpikir tentang cinta dan Tuhan dalam bangunan konstruksi eksistensialisme mereka. Namun dalam artikel ini, konsep relasi antarmanusia Martin Buber yang akan dijadikan sebagai pijakan untuk melihat konsep yang sama yang terdapat dalam nilai-nilai kebudayaan Bugis.

Pemikiran filosofis Buber didasarkan pada pendekatan dialogis dalam memahami manusia. Asumsinya adalah bahwa kehidupan yang nyata adalah sebuah pertemuan. Manusia dilahirkan sebagai pribadi yang berlainan satu dengan yang lainnya untuk saling berkomunikasi dan terjadinya sebuah dialog di antara mereka (Lathief, 2010: 19).

Buber dengan asumsi dasar tersebut, membangun paradigma mengenai manusia. Manusia senantiasa membangun relasinya dengan lingkungan, sesama manusia dan Tuhannya. Bertens menjelaskan pandangan Buber tersebut dalam bukunya. 
"Manusia mempunyai dua relasi yang fundamental berbeda: di satu pihak relasi dengan benda-benda dan di lain pihak relasi dengan sesama manusia dan Allah. Relasi yang pertama disebut Ich-Es (I-It), dan relasi yang kedua diberi nama Ich-Du (I-Thou). Dalam bahasa Indonesia barangkali dapat dikatakan Aku-Itu dan Aku-Engkau. Buber mengatakan bahwa karena dua relasi ini "Aku" sendiri bersifat dwiganda, sebab "Aku" yang berhubungan dengan "Itu" berlainan dengan "Aku" yang berhubungan dengan "Engkau". Tetapi biarpun relasi-relasi bisa berbeda, namun "Aku" tidak pernah tanpa relasi; "Aku" tidak pernah merupakan suatu "Aku" yang terisolasi" (Bertens, 2002: 180).

Relasi yang ada dalam pandangan Buber adalah relasi AkuEngkau, dan relasi Aku-Itu. Relasi Aku-Engkau bermakna hubungan tersebut adalah hubungan antarsesama manusia dan hubungan yang terjalin antara manusia sebagai umat dengan Tuhannya. Relasi Aku-Itu bermakna bahwa manusia juga tetap menjalin hubungan dengan benda-benda atau yang dibendakan di sekitarnya, atau bisa dikatakan bahwa manusia menjalin relasi dengan alam atau lingkungannya.

Buber memberikan penyebutan lain pada kedua bentuk relasi tersebut. Buber menyebutnya "pengalaman" pada relasi Aku-Itu, sedangkan pada relasi Aku-Engkau disebutnya dengan "hubungan". Pandangan Buber tentang "pengalaman" (erfahrung) dan "hubungan" (beziehung) diuraikan oleh Lathief dalam tulisannya.

"Jika yang terjadi hubungan Aku-Itu, maka dunia yang dicitrakan adalah dunia benda-benda, sesuatu yang dibendakan, kepemilikan, dan penguasaan atas yang lain. Hubungan yang demikian ini menandai dunia sebagai Erfahrung (pengalaman), tetapi oleh Buber dipergunakan sebagai penunjuk hubungan dengan benda-benda. Sedangkan istilah Beziehung (hubungan) menandai relasi Aku-Engkau, hubungan yang dikhususkan bagi manusia-manusia. Hal ini memberi citra hubungan yang sejati atau genuinitas dalam dialog antarmanusia" (Lathief, 2010: 19). 
Hal tersebut diungkapkan oleh Buber (1937: 6) dalam karya monumentalnya yang berjudul I and Thou atau dalam bahasa Jermannya Ich und $D u$, yang kemudian membuatnya menjadi sangat dikenal sebagai seorang pemikir dalam filsafat eksistensialisme. As experience, the world belongs to the primary word "I-It". The primary word "I-Thou" establishes the world of relation.

Kedua pola tersebut dalam perspektif Buber ini, tidak pantas jika diputarbalikkan, misalnya Thou atau Engkau dianggap sebagai benda atau dibendakan, maka di dalamnya tidak terdapat cinta. Thou bukanlah benda atau objek.

"When "Thou" is spoken, the speaker has no thing for his object. For where there is a thing there is another thing. Every "It" is bounded by others; "It" exists only through being bounded by others. But when "Thou" is spoken, there is no thing. "Thou" has no bounds. When "Thou" is spoken, the speaker has no thing; he has indeed nothing. But he takes his stand in relation" (Buber, 1937:4).

Memang manusia tidak dapat hidup tanpa It, tetapi bukan berarti bahwa manusia harus tunduk kepada It. Orang yang hanya hidup dengan It saja, ia sesungguhnya bukanlah manusia. If a man lets "It" have the mastery, the continually growing world of "It" overruns him and robs him of the reality of his own "I" (Buber, 1937: 46).

Ketika pola hubungan Aku-Itu atau I-It yang terbangun dalam hubungan sesama manusia, maka Engkau tidak lagi sesama manusia bagi Aku, melainkan Engkau adalah suatu benda, objek yang dapat aku gunakan. Perjalanan sejarah telah mencatat, jika pola hubungan Aku-Engkau semakin terkikis dalam relasi yang seharusnya terjalin antarsesama manusia yang penuh dengan cinta kasih. Pola hubungan Aku-Itu atau I-It terhadap sesama manusia semakin menunjukkan dominasinya, saling mengobjektifikasi. Pengandaian filosofis Buber tersebut, menyerupai kritik atas kebudayaan modern yang dikemukakan oleh begitu banyak filsuf abad ke-20, khususnya berhubungan dengan peranan ilmu pengetahuan dan teknologi yang mematikan relasi-relasi antarmanusia (Bertens, 2002: 181). 
Pola hubungan Aku-Itu yang diterapkan dalam hubungan sesama manusia tidak akan pernah tumbuh perasaan cinta sesama. Yang ada adalah subjek-objek atau hubungan antara pemilik benda dengan benda miliknya. Padahal seharusnya disadarai bahwa Aku menjadi Aku karena Engkau, bukan karena Itu. Hal ini tersirat makna bahwa manusia saling membutuhkan.

Relasi Aku-Engkau hanya bisa terealisasi jika di dalamnya terdapat cinta kasih. Di sini, cinta merupakan spirit yang hadir antara AkuEngkau, spirit tidak hadir di dalam Aku. Spirit in its human manifestation is a response of man to his Thou.... Spirit is not in the I, but between I and Thou. It is not like the blood that circulates in you, but like the air in which you breathe (Buber, 1937:39).

Relasi Aku-Engkau tidak terbatas hanya pada hubungan sesama manusia. Justru relasi Aku-Engkau memuncak dalam relasi Aku dengan Allah sebagai Engkau yang abadi. Allah adalah Engkau yang tidak mungkin dijadikan Itu. Ia tidak dapat didefinisikan atau dilukiskan. Manusia hanya dapat mengenal Allah dalam ketaatan dan kepercayaan (Bertens, 2002: 181). Karena itulah, Buber dikenal sebagai salah seorang eksistensialis religius yang tidak menafikan Tuhan sebagai Engkau yang absolut.

Buber dalam konsepnya tersebut berusaha menempatkan suatu hubungan pada posisinya masing-masing, posisi yang tidak memungkinkan untuk diputarbalikkan. Pola Aku-Itu adalah hubungan yang seharusnya terjalin hanya antara manusia dan benda. Ketika pola ini digunakan dalam membangun hubungan antarmanusia, maka yang terjadi adalah objektifikasi manusia yang seharusnya menjadi subjek, eksploitasi terhadap manusia, dan berbagai macam tragedi kemanusiaan akan memunculkan sosok aslinya. Untuk membangun hubungan yang harmonis antarsesama manusia, yang didasari atas cinta kasih, maka pola hubungan yang tepat adalah pola Aku-Engkau, hubungan yang kemudian memuncak pada Engkau yang absolut, Engkau yang bukan dan tidak mungkin bisa dibendakan. Jadi, Aku-Itu adalah hubungan antara subjek-objek, dan Aku-Engkau adalah bentuk hubungan antar subjek. 


\section{MANUSIA DALAM PANDANGAN BUDAYA BUGIS}

Manusia, yang dalam bahasa Bugis disebut tau, ketika diuraikan dalam perspektif nilai-nilai budaya Bugis maka tidak akan bisa lepas dari narasi yang terungkap dalam epos La Galigo. Epos ini lahir di tengah-tengah masyarakat Bugis yang menggambarkan proses penciptaan umat manusia, lengkap dengan segala perilaku manusia, dan nilai-nilai yang melingkupi serta mengiringi perjalanan hidup manusia di dunia tengah atau Ale Kawa'.

Jika merunut pada epos La Galigo, konsep penciptaan manusia akan ditemukan sangat berbeda dengan konsep penciptaan manusia yang terdapat dalam kitab-kitab yang dimiliki oleh agama-agama besar dunia, khususnya kitab-kitab suci yang dimiliki oleh agama-agama Abrahamik. Proses penciptaan manusia pada epos La Galigo dimulai di Boting Langi' atau dunia atas.

Proses penciptaan yang dimaksud di sini adalah proses perubahan eksistensi tokoh Batara Guru sebagai dewa yang diturunkan atau manurungnge menjadi manusia yang menghuni Ale Kawa', bukan proses penciptaan dari tidak ada menjadi ada, atau proses penciptaan dari suatu bentuk ke bentuk yang lain. Sebagai manusia, Batara Guru kelak akan memikul berbagai macam kewajiban, terutama melakukan penyembahan kepada para dewata yang menghuni Boting Langi dan Peretiwi. Boting Langi atau dunia atas, Ale Kawa atau dunia tengah, dan Peretiwi atau dunia bawah adalah tiga dimensi dalam kosmologi Bugis. Proses penciptaan manusia pada epos La Galigo diceritakan pada episode awal yang dikenal dengan episode Mula Tau atau manusia pertama.

Proses penciptaan mula tau atau manusia pertama dalam konsep La Galigo merupakan sebuah proses perubahan eksistensi. Perubahan eksistensi yang dimaksud adalah perubahan eksistensi Batara Guru sebagai dewa menjadi Batara Guru sebagai manusia, yang merupakan putra sulung dan putra mahkota Patoto' $e$, maharaja dewata yang bertahta di Boting Langi, bersama Datu Palinge, permaisurinya. Hal tersebut diceritakan ketika berlangsung musyawarah agung para dewa yang membicarakan tentang siapa yang akan diturunkan ke Ale Kawa' sebagai mula tau yang kelak akan menyembah kepada para dewa. $\mathrm{Mu}-$ 
syawarah agung tersebut sangat alot dan penuh pertentangan dalam menentukan siapa di antara anak Patoto'e yang akan diturunkan untuk menjadi manusia pertama atau mula tau ke dunia tengah. Pada akhirnya Batara Guru yang disepakati dalam musyawarah agung tersebut untuk diturunkan menjadi manusia pertama. Setelah menemukan kesepahaman tentang siapa di antara anak Patoto'e dan Datu Palinge' yang akan diturunkan ke bumi untuk menjadi manusia pertama dan menjadi tunas untuk melahirkan keturunannya sebagai penghuni bumi, maka dilangsungkan prosesi untuk mempersiapkan Batara Guru diturunkan ke dunia tengah.

Prinsip pada konsep penciptaan manusia dalam La Galigo didasari oleh persoalan eksistensi kedewaan para penghuni Boting Langi. Ide pertama untuk menjelmakan manusia ke Ale Kawa' atau dunia tengah datang dari seorang abdi yang baru saja kembali dari kolong langit bermain-main dengan menurunkan topan, mengadu petir, menyabung kilat, permainan khas para penghuni Boting Langi.

Kalimat dalam naskah La Galigo, "Kita bukanlah dewata, apabila tak satu pun orang di kolong langit menyeru tuan kepada Batara." Beberapa kali itu diucapkan oleh Patoto'e ketika meminta persetujuan atas ide menjelmakan manusia di Ale Kawa'. Patoto'e pertama kali mengucapkan kalimat tersebut ketika meminta persetujuan sang permaisuri, Datu Palinge' atau biasa juga disebut Mutia Unru', untuk menurunkan salah seorang anak mereka ke bumi sebagai manusia, yang kelak akan memberikan pengakuan atas eksistensi kedewaan mereka yang bertahta di Boting Langi' dan di Peretiwi, dengan cara melakukan penyembahan.

"Kita bukanlah dewata, apabila tak satu pun orang di kolong langit menyeru tuan kepada Batara". Kalimat tersebut menunjukkan bahwa para dewa butuh untuk di-ada-kan atau untuk dihadirkan, atau untuk diakui keber-ada-an mereka. Mereka tidak akan pernah ada ketika tidak ada pengakuan. Pengakuan sebagai dewa tentunya harus berasal dari pihak lain yang bukan dewa. Dewa sebagai entitas akan ada ketika ada entitas lain yang meng-ada-kan. Berdasarkan hal tersebut, maka Patoto'e membutuhkan entitas lain, yaitu manusia, untuk 
menjadi pengaku. Dengan alasan itulah Patoto'e ingin menjelmakan manusia di muka bumi agar manusia bisa menjadi penyembah yang mengakui keberadaan dewa di Boting Langi' dan di Peretiwi.

Manusia dalam konteks nilai-nilai budaya Bugis dipandang sebagai sebuah entitas yang terdiri dari dua unsur, yaitu unsur luar dan unsur dalam. Unsur luar manusia yang dimaksud adalah unsur fisik, unsur yang dapat terjangkau oleh pancaindra, yaitu tubuh yang dalam bahasa Bugis disebut watakkale. Kemudian, unsur dalam pada manusia adalah unsur-unsur yang immaterial atau non-fisik yang kehadirannya tak terjangkau oleh pancaindra. Unsur tersebut dikategorikan sebagai jiwa yang dalam bahasa Bugis disebut bannapati. Namun dalam pandangan nilai-nilai budaya Bugis terdapat beberapa unsur lain yang terkadang disinonimkan dengan bannapati, unsur tersebut di antaranya adalah ininnawa, sumange' dan tiyo atau tiniyo. Kern, seorang peneliti epos La Galigo berkebangsaan Belanda, menjelaskan hal tersebut dalam katalogus La Galigo yang dibuatnya.

"Ininnawa" - hati nurani, isi kalbu manusia tampil juga sebagai suatu substansi=bannapati. ... Yang dipaparkan disini adalah gambaran-gambaran yang diperoleh setelah membaca kisah-kisah I La Galigo, yang dipandang sebagai suatu keseluruhan. Batas-batas yang tajam tidaklah dapat ditarik di sini, bahkan hampir-hampir tak ada yang dapat dinamakan batas. Oleh karena akhirnya selalu ada saja naskah yang dapat ditemukan, di mana misalnya "sumange'" dan "bannapati" disamakan, "bannapati" dengan "tiniyo" ... (Kern, 1993: 18-19).

Selain yang disebutkan di atas, To Ciung, salah seorang cendekiawan Bugis yang berasal dari Kerajaan Luwu, yang biasa disebut dengan gelar Maccae ri Luwu, menyebut jiwa dengan kalawing ati.

"Accita tauwo mumadeceng kalawing ati. Apa' iya sininna deceng enrengnge upe'e, kumanengngi pole ri tau madeceng kalawing atie. Apa' iyanaritu tau ri lalenna taue..."

“Berpandanganlah sebagai manusia dan perbaiki sikap ji- 
wamu. Sebab, semua kebaikan dan kemujuran sumbernya berasal dari orang yang baik sikap jiwanya. Itulah sebenarnya yang disebut, manusia di dalam manusia..." (To Ciung dalam Ibrahim, 2003: 71-72).

Dari sekelumit uraian yang dipaparkan di atas, bisa dikatakan jika manusia atau tau dalam epos La Galigo dianggap sebagai sebuah entitas titisan dewata yang diturunkan ke dunia tengah atau Ale Kawa' untuk menyembah atau menegakkan eksistensi dewata yang bertahta di Boting Langi dan di Peretiwi. Manusia Bugis yang kemudian mengidentifikasi diri sebagai sebuah entitas yang dalam dirinya terdiri dari dua unsur, yaitu watakkale dan bannapati, yang terkadang disinonimkan dengan kata yang lain.

\section{KONSEP RELASI I - IT DALAM NILAI-NILAI BUDAYA BUGIS}

Pola relasi dalam kehidupan manusia, yang saling mengobjektifikasi atau saling meniadakan sebagai manusia, dalam konsep filsafat dialogis Martin Buber dikenal dengan pola relasi I - It atau Aku - Itu. Sementara itu, jika menengok ke dalam konteks budaya masyarakat Bugis, pola relasi semacam itu dikenal dengan pola relasi sipakasiri'.

Sipakasiri' pada dasarnya merupakan sebuah tindakan yang sangat tabu untuk dilakukan di dalam nilai-nilai budaya Bugis. Kata sipakasiri' bersumber dari kata dasar siri'. Siri' bermakna martabat kemanusiaan, kehormatan, atau harga diri, serta sering juga dimaknai dengan rasa malu. Jika dilihat maknanya secara mendalam, maka bisa dikatakan kalau siri' itu adalah jiwa bagi manusia Bugis-Makassar, sesuatu yang sangat mendasar dalam tatanan hidup mereka.

Kata siri' tersebut mengacu pada kata siri atau biasa juga disebut dengan leko', yang lebih dikenal dengan daun sirih (Piperis Betle Folium), yang terdapat dalam naskah La Galigo pada episode Mula Tau.

“Nama tanaman siri yang disebut dalam Sure' Selleang I La Galigo merupakan pelambang terhadap kata siri'. Dikemukakan, bahwa hutan-hutan belantara (ale'-ale') yang dinyatakan sebagai penjelmaan tanaman siri merupakan pelam- 
bang bagi kehidupan di dunia tengah (Ale Kawa')" (Salahuddin dalam Marzuki, 1995: 103).

Ketika kata siri' tersebut mengalami afiksasi dengan ditambahkan prefiks paka, dan sebelum prefiks paka terdapat kata si yang berarti saling, dan kemudian menjadi sipakasiri', maka maknanya akan sangat negatif, akan menjadi sebuah pola tindakan yang saling tidak memanusiakan. Sebuah pola tindakan yang sangat tabu dilakukan di tengahtengah masyarakat Bugis-Makassar, yaitu pola tindakan yang bertentangan dengan siri'.

Kata sipakasiri' jika dilihat secara terminologi, akan bermakna saling mempermalukan, mengabaikan harkat dan martabat serta kehormatan orang lain, atau bisa juga dikatakan bahwa sipakasiri' itu adalah suatu sikap yang melanggar siri' orang lain, atau meniadakan manusia lain sebagai subjek. Manusia adalah subjek yang patut untuk dihargai martabat dan kehormatannya sebagai manusia.

Sipakasiri' tidak lain merupakan sebuah pola relasi atau sebuah pola tindakan dalam menjalin sebuah hubungan yang tidak menghadirkan manusia sebagai subjek lain. Adapun hal ini hanya ada Aku dan Sesuatu, atau pola relasi I-It (Aku-Itu) dalam konsepsi Martin Buber. Ketika menengok ke dalam konteks nilai-nilai budaya Bugis, pola relasi sipakasiri' sangat rawan untuk terjadi pada hal-hal yang menyangkut kepemilikan sesuatu dan persoalan perkawinan. Adapun tidak menutup kemungkinan pola relasi sipakasiri' ini dapat terjadi pada persoalan-persoalan kehidupan yang lain.

Nilai-nilai budaya Bugis mengonsepsi pola relasi sipakasiri' sebagai sebuah pelanggaran nilai-nilai kemanusiaan. Seperti diketahui bahwa siri' merupakan substansi manusia Bugis-Makassar, atau bisa dikatakan bahwa siri' itu adalah jiwa bagi manusia Bugis-Makassar. Ketika pola relasi sipakasiri' hadir di tengah-tengah pergulatan kehidupan masyarakat, maka yang terjadi adalah objektifikasi terhadap manusia lain. Bahkan ketika pola relasi semacam ini dipraktekkan di tengah-tengah kehidupan masyarakat Bugis-Makassar, hal tersebut cenderung memicu berbagai macam bentuk reaksi yang bisa berujung 
pada tindakan yang saling meniadakan. Adapun hal ini akan menjadi sesuatu yang termaklumi ketika raja-raja dan keturunannya bertindak melampaui batas nilai-nilai kemanusiaan, karena mereka dianggap sebagai titisan dewa. Hal tersebut umum terjadi pada pemerintahanpemerintahan tradisional, termasuk pada pemerintahan tradisional masyarakat Bugis yang tergambarkan dalam epos La Galigo. Hal ini bukan berarti bahwa hal tersebut bisa dikatakan sebagai sebuah kebenaran dan dipraktekkan hingga saat ini.

La Galigo, sebagaimana mitos-mitos lainnya, dihadirkan oleh rezim kekuasaan dengan maksud untuk memberikan legitimasi kepada penguasa sebagai titisan dewa agar kebijakan-kebijakan serta tindakan-tindakan yang mereka lakukan dianggap sebagai sumber kebenaran. Hal tersebut memberikan ruang yang sangat luas kepada para penguasa, yang notabene adalah titisan dewa, untuk melakukan tindakan-tindakan dan kebijakan-kebijakan yang melampaui batas nilainilai kemanusiaan.

Cerita dalam epos La Galigo, yang mengandung unsur-unsur objektifikasi terhadap manusia, tidak terlepas dari kehadiran epos $\mathrm{La}$ Galigo sebagai sebuah mitos yang dihadirkan oleh rezim penguasa. Mitos ini dilahirkan untuk digunakan sebagai alat legitimasi kekuasaan. Fenomena semacam itu hadir hampir di setiap bentuk pemerintahan tradisional yang dimiliki oleh setiap kelompok masyarakat. Ketika nilai-nilai kemanusiaan dianggap bukan sesuatu hal yang penting, kekuasaan dianggap sebagai hal yang terpenting dan disakralkan melampaui nilai-nilai kemanusiaan.

\section{KONSEP RELASI I - THOU}

\section{DALAM NILAI-NILAI BUDAYA BUGIS}

Konsep relasi antarmanusia yang saling memanusiakan dan saling menghargai, dalam nilai-nilai budaya Bugis dikenal dengan pola relasi sipassiriki. Pola relasi sipassiriki yaitu pola relasi yang termanifestasikan dalam konteks sipakatau dan sipakalebbi. Pola relasi sipassiriki adalah konsepsi budaya yang mengajarkan dan menuntun masyarakat 
Bugis bagaimana seharusnya sebagai manusia berperilaku terhadap sesama manusia, atau bagaimana seorang manusia memanusiakan manusia lain tanpa mengenal perbedaan.

\section{Sipakatau}

Sipakatau biasa diartikan dengan saling memanusiakan. Sipakatau mengandung makna saling menjadikan manusia atau saling menghadirkan sebagai entitas yang memiliki kesadaran terhadap diri dan kehidupannya. Sipakatau berprinsip bahwa ketika Aku manusia maka Engkau pun adalah manusia, ketika Engkau adalah manusia maka Aku pun adalah manusia. Prinsip ini tidak mengenal status sosial, agama, dan keturunan atau ras seseorang. Sipakatau mengandung makna ke-saling-an atau "hubungan yang saling" di antara sesama manusia. Adapun bahasa Buber itu disebut dengan relation is mutual, yang di dalamnya tidak mengandung objek di antara yang "saling", dan yang ada adalah keduanya merupakan subjek.

Pakatui ri padammu rupa taue merupakan ungkapan dalam bahasa Bugis yang berarti manusiakanlah sesamamu manusia. Adapun ungkapan tersebut mengandung makna ke-saling-an di antara sesama manusia, dan juga mengandung makna tidak mengenal perbedaan. Makna ke-saling-an bisa ditemukan pada kata pakataui, saling memanusiakanlah. Sementara itu, yang mengandung makna tidak mengenal perbedaan bisa dilihat pada kalimat ri padammu rupa taue. Kalimat tersebut mengandung makna bahwa rupa tau adalah entitas makhluk yang berkesadaran yaitu manusia, tanpa ada unsur pembeda di antara sesama rupa tau atau manusia. Jadi, setiap rupa tau atau manusia harus mendapat perlakuan sesuai martabatnya sebagai manusia tanpa mengenal unsur-unsur pembeda. Apakah dia manusia berkulit hitam atau berkulit putih, Austronesia atau Kaukasus, Bugis atau Jawa, Hin$\mathrm{du}$ atau Islam, perempuan atau laki-laki, selama sebagai manusia maka harus mendapat perlakuan sebagai manusia.

Hal semacam itu diuraikan oleh Mattulada dalam bukunya, yang menjelaskan tentang nilai-nilai kemanusiaan yang terkandung dalam sebuah naskah Bugis kuno yang berjudul Latoa. 
"Kalau kita memperhatikan sekian buah pikiran dalam Latoa sebagai himpunan pedoman tentang nilai dan kaidahkaidah normatif yang ideal bagi orang Bugis pada jamannya, kita akan menjumpai bahwa pola-pikir itu telah memberikan tempat terhormat kepada manusia sebagai makhluk yang bermartabat, sederajat dengan sesamanya, apa pun kedudukan sosial dan asal keturunannya" (Mattulada, 1995: 87).

Memanusiakan manusia atau sipakatau, atau konsep saling memanusiakan dalam nilai-nilai budaya bugis, keberadaannya tidak dapat dipisahkan dengan konsep nilai yang lain, yaitu siri' dan pesse. Ketiga konsep nilai tersebut memiliki keterkaitan yang sangat erat karena konsep sipakatau itu sendiri didasarkan pada konsep siri' dan pesse, konsep yang berbicara tentang manusia dan perilaku manusia terhadap sesama manusia.

Manusia Bugis hadir dengan membawa nilai-nilai siri'nya, salah satu nilai utama dalam budaya Bugis yang senantiasa tertanam dan menyertai perjalanan hidup manusia Bugis. Dikatakan demikian karena substansi manusia Bugis ada pada siri'nya. Siri' merupakan penegasan ke-manusia-an manusia Bugis. Hal tersebut terungkap dalam sebuah ungkapan Bugis yang mengatakan, engka siri'mu, engka muto siri'ku, aja' na to sipakasiri', engkau memiliki siri', aku pun memilikinya, hendaknya manusia jangan saling menistakan sebagai sesama manusia. Maksud dari ungkapan tersebut adalah bahwa di dalam diri setiap manusia terdapat siri', Aku dan Engkau adalah manusia yang samasama memiliki siri', hendaknya Aku dan Engkau tidak saling menistakan, meniadakan atau mengobjektifikasi, tetapi hendaknya antara Aku dan Engkau saling menjaga siri' atau saling memanusiakan. Jagai siri'ku ujagai toi siri'mu, Engkau jaga siri'ku maka Aku pun akan menjaga siri' Kamu. Ungkapan tersebut bermakna, ketika Engkau memanusiakan Aku maka Aku pun akan memanusiakan Kamu. Pandangan semacam itulah yang dimaksudkan dengan sipakatau atau saling memanusiakan dalam nilai-nilai budaya Bugis.

Adapun demikian, siri' akan berjalan pincang ketika dipraktek- 
kan tanpa disertai dengan nilai pesse. Siri' senantiasa bergandengan dengan pesse atau nilai yang biasa diartikan dengan empati atau rasa pedih yang mendalam ketika melihat penderitaan orang lain. Pesse merupakan nilai yang memperkuat dan memperkokoh nilai kemanusiaan yang terdapat dalam siri'. Nilai pesse inilah yang senantiasa mengontrol berlangsungnya dialog siri' antara Aku dan Engkau, karena nilai pesse mengajarkan kepada manusia untuk saling mengasihi dan saling berempati.

Perilaku sipakatau yang terdapat dalam diri manusia Bugis berangkat dari konsep nilai siri' dan pesse, yang dalam prakteknya senantiasa terjalin dialog di antara manusia. Adapun konsep Buber disebutkan bahwa dialog senantiasa berlangsung antara I and Thou atau antara Aku dan Engkau. Konsep sipakatau yang merupakan dimensi pemahaman masyarakat Bugis terhadap relasi yang berlangsung antarsesama manusia, senantiasa termanifestasikan dalam kehidupan sehari-hari masyarakat Bugis.

\section{Sipakalebbi}

Pemahaman tentang konsep sipakalebbi dalam nilai-nilai budaya Bugis tidak bisa dilepaskan begitu saja dari keterkaitannya dengan konsep sipakatau. Kedua konsep tersebut saling berkaitan erat. Konsep sipakatau menjadi dasar yang kokoh dalam menerapkan sipakalebbi sebagai sebuah konsep di tengah kehidupan masyarakat yang semakin kompleks dan cenderung saling meniadakan. Sipakalebbi merupakan salah satu konsep ke-saling-an dalam praktek nilai-nilai budaya Bugis, yang bermakna saling memuliakan atau saling menghargai di antara sesama manusia.

Sipakalebbi berasal dari kata dasar lebbi yang berarti mulia. Sipakalebbi dalam hal ini bermakna bahwa setiap manusia harus memberikan perlakuan mulia kepada manusia yang lain. Ini karena setiap manusia lahir dengan membawa alebbireng atau kemuliaan, dan di antara sesama manusia wajib untuk saling memuliakan.

Sipakalebbi merupakan salah satu implementasi yang lebih luas dari konsep sipakatau atau saling memanusiakan. Terdapat sebuah ungkapan dalam bahasa Bugis yang merujuk pada konsep sipakalebbi 
tersebut, yaitu pakalebbi i ri padammu rupa taue, "muliakanlah sesamamu manusia". Ungkapan tersebut bermakna sama dengan konsep sipakatau, yaitu saling memanusiakan, saling menghadirkan. Ungkapan pakalebbi i ri padammu rupa taue maknanya hampir sama dengan ungkapan pakataui ri padammu rupa taue. Ketika ungkapan pakataui ri padammu rupa taue bermakna memanusiakan sesama manusia, maka ungkapan pakalebbi i ri padammu rupa taue bermakna memuliakan sesama manusia.

Konsep sipakalebbi itu sendiri merupakan bentuk penghargaan dari seorang manusia terhadap kemuliaan yang melekat atau disematkan pada diri manusia lainnya. Menurut pemahaman masyarakat Bugis, tidak ada manusia yang dilahirkan ke dunia ini tanpa membawa kemuliaannya. Semua manusia dilahirkan dengan kemuliaannya masing-masing. Karena itulah setiap manusia dianggap sepantasnya untuk memberi dan menerima perlakuan mulia tanpa mengenal perbedaan.

Bersumber dari pemahaman tersebut di atas, maka dikenal adanya konsep sipakalebbi sebagai sebuah nilai dalam budaya Bugis. Sebagaimana konsep sipakatau, konsep sipakalebbi juga tidak mengenal perbedaan. Sepanjang sebagai manusia maka wajib untuk diberi kemuliaan sebagai seorang manusia. Ungkapan pakalebbi i ri padammu rupa taue menegaskan hal tersebut, dan tidak memberi ruang pemahaman untuk saling menistakan karena adanya perbedaan. Bahkan ungkapan tersebut meniscayakan untuk saling memuliakan nilai-nilai kemanusiaan yang melekat dan hadir pada diri setiap seorang manusia. Seorang manusia bisa hadir karena kehadiran manusia lain.

\section{KONSEP RELASI I - ETERNAL THOU}

\section{DALAM NILAI-NILAI BUDAYA BUGIS}

Pada dasarnya, konsep relasi yang dibangun oleh Martin Buber yang dikenal dengan pola relasi I-Eternal Thou merupakan bangunan pola relasi antara Aku manusia dengan Engkau supernatural atau biasa disebut Engkau yang Abadi atau Tuhan. Ketika dibawa ke dalam konsepsi budaya yang dibangun oleh leluhur masyarakat Bugis, maka yang dimaksud dengan Eternal Thou atau supernatural adalah dewata 
seuwwae, dewata sang penguasa jagad. Konsep relasi yang terbangun antara manusia dengan unsur supernatural dalam konsepsi budaya Bugis disebut mappesona ri dewata seuwwae.

Mappesona ri dewata seuwwae merupakan sebuah konsepsi dalam nilai-nilai budaya Bugis yang bermakna mendekatkan diri kepada dewata, membangun komunikasi yang intens demi menjaga dan memelihara relasi atau hubungan dengan dewata seuwwae. Mappesona ri dewata seuwwae, dalam pemahaman masyarakat Bugis, bukan sekedar melakukan ritual penyembahan kepada dewata dengan menadahkan tangan ke Boting Langi' dan ke Peretiwi, tetapi lebih dari itu, berbuat dengan menjalankan tugas sebagai manusia, yaitu menjadi tunas untuk mengembangkan kehidupan, serta memberikan cahaya kepada kehidupan di Ale Kawa' atau dunia tengah.

Memantangkan kayu sengkonang merupakan tonggak dari relasi yang senantiasa berlangsung antara manusia dan dewata. Ketika manusia senantiasa menjalankan tugasnya sebagai manusia dengan mengembangkan kehidupan dan menjaga agar cahaya kehidupan tetap berpijar dan tidak meredup, maka kayu sengkonang, sebagai simbol dari relasi antara manusia dengan dewata seuwwae, akan tetap berdiri kokoh. Proses dialog antara kedua entitas tetap berlangsung.

Relasi semacam itulah yang dalam konsepsi nilai-nilai budaya Bugis disebut dengan konsep mappesona ri dewata seuwwae, mendekatkan diri untuk berkomunikasi dengan dewata seuwwae. Berkomunikasi yang dimaksud adalah menjalankan tugas sebagai manusia, yang telah ditetapkan oleh Patoto'e sebelum manusia dijelmakan ke dunia tengah, di samping tetap melakukan ritual penghambaan dengan menengadahkan tangan ke Boting Langi' dan ke Peretiwi.

\section{RELEVANSI KAJIAN RELASI ANTARMANUSIA DALAM NILAI-NILAI BUDAYA BUGIS DENGAN USAHA PEMBANGUNAN HAK ASASI MANUSIA DI INDONESIA}

Banyak nilai kemanusiaan yang bisa dipetik dari khasanah kebudayaan yang ada di setiap etnis di Indonesia, yang kemudian bisa dikontekstualisasikan sebagai pedoman membangun relasi dalam keberagaman yang harmonis, yang bisa berkontribusi secara konseptual 
terhadap penguatan Hak Asasi Manusia di Indonesia. Apalagi di era sekarang ini, wacana HAM atau Hak Asasi Manusia menjadi salah satu wacana yang semakin kencang disuarakan oleh masyarakat dunia.

Mencermati konsep-konsep Hak Asasi Manusia, termasuk yang terdapat dalam Universal Declaration of Human Rights dan Undangundang Republik Indonesia Nomor 39 tahun 1999 tentang Hak Asasi Manusia, tidak ditemukan pembedaan perlakuan antarmanusia, apakah seseorang itu berkulit hitam atau putih, ataukah warga negara lain, semuanya sama, selama memiliki entitas sebagai manusia maka seseorang berhak mendapatkan haknya untuk diperlakukan sebagai manusia.

Selama ini pemerintah Indonesia, dalam upaya penegakan Hak Asasi Manusia, hanya menggunakan pendekatan-pendekatan hukum dan politik. Belum pernah terdengar adanya upaya-upaya untuk menyentuh model pendekatan kultural atau pendekatan budaya sebagai salah satu upaya untuk membangun penegakan HAM di Indonesia.

Secara konseptual masyarakat Nusantara sudah memiliki konsep-konsep penegakan Hak Asasi Manusia walaupun tidak dikenal adanya konsep Hak Asasi Manusia seperti yang dikenal saat ini, yaitu konsep yang diadopsi dari konsep HAM dunia Barat. Konsep penegakan Hak Asasi Manusia yang lahir di tengah-tengah masyarakat Nusantara merupakan kearifan lokal yang banyak berupa petuah-petuah, syair-syair dan aturan-aturan adat, baik dalam bentuk lisan maupun dalam bentuk tertulis. Petuah-petuah, syair-syair dan aturan-aturan adat yang lahir dari kecerdasan lokal masyarakat Nusantara sangat kaya dengan nilai-nilai kemanusiaan, nilai-nilai yang sangat memuliakan dan menjunjung tinggi harkat dan martabat manusia.

Ketika berbicara tentang upaya penegakan Hak Asasi Manusia, maka keberadaan nilai-nilai budaya setempat tidak bisa begitu saja dikesampingkan. Ini karena nilai-nilai budaya atau kearifan lokal masyarakat setempat banyak mengandung nilai-nilai yang sangat memuliakan keberadaan manusia. Nilai-nilai sipakatau dan sipakalebbi yang terdapat dalam kebudayaan Bugis, misalnya, merupakan nilai-nilai yang menempatkan manusia pada posisi istimewa. 
Wacana kearifan lokal, seperti konsep sipakatau dan sipakalebbi yang hadir sebagai nilai-nilai dalam kebudayaan masyarakat Bugis sebagaimana telah diuraikan di atas, menunjukkan bahwa kajian relasi antarmanusia yang terdapat dalam nilai-nilai budaya Bugis tersebut memiliki relevansi yang kuat dengan usaha pembangunan pemahaman tentang Hak Asasi Manusia atau HAM, khususnya di Indonesia. Kajian tersebut di atas dapat juga dijadikan sebagai sumbangan pemikiran atas persoalan kemanusiaan yang tidak berhenti mendera bangsa ini. Paling tidak, bisa memberikan pencerahan pemahaman tentang entitas manusia sebagai makhluk yang berkesadaran, yang memiliki hak-hak mendasar untuk hidup dan menjalani kehidupannya.

\section{SIMPULAN}

Pemahaman tentang manusia dalam nilai-nilai budaya Bugis dapat dimulai penelusurannya dengan berangkat dari pembacaan terhadap naskah La Galigo, sebuah epos yang diawali dengan episode mula tau atau manusia pertama yang diturunkan dari Boating Langi. Berawal pada episode pertama tersebut, dapat dilihat bagaimana budaya Bugis memandang manusia sebagai entitas yang berkesadaran.

Sebagai makhluk yang berkesadaran, manusia Bugis dalam perjalanan kehidupannya kemudian mengkonstruksi nilai-nilai yang merupakan kreasi kesadaran kemanusiaan manusia Bugis. Dalam hal ini, itu termasuk mengkonstruksi nilai-nilai kemanusiaan yang terpatri dalam ruang-ruang kesadaran mereka. Ruang-ruang kesadaran manusia Bugis kemudian menghasilkan konsep-konsep relasi antarmanusia yang mengantarkan manusia Bugis untuk menghadirkan manusia lain sebagai subjek, sebagaimana dirinya sebagai subjek, untuk saling menghadirkan dan berdialog antarsubjek. Konsep relasi antarmanusia yang lahir dari ruang kesadaran manusia Bugis yaitu konsep sipassiriki, sebuah konsep yang kemudian termanifestasi dalam pola sipakatau dan sipakalebbi.

Pada prinsipnya, dalam pemahaman budaya Bugis, ketika manusia berupaya untuk memanusiakan dan saling memuliakan sesama manusia maka upaya tersebut merupakan upaya untuk membangun relasi, yang juga bentuk pengabdian kepada Yang Maha Kuasa, atau 
dewata seuwwae. Kepercayaan tradisional masyarakat Bugis berdasar pada keyakinan bahwa manusia adalah makhluk yang dijelmakan ke Ale Kawa' oleh dewata seuwwae untuk menegakkan kehidupan, bukan untuk merusak kehidupan. Menegakkan kehidupan berarti membangun relasi dan dialog dengan Yang Abadi, yaitu Tuhan, karena menegakkan kehidupan di dunia adalah kehendak Sang Maha Kuasa, bukan pilihan manusia. Konsep pengabdian kepada dewata seuwwae, oleh masyarakat Bugis dikenal dengan konsep mappesona ri dewata seuwwae.

Bersumber dari pemahaman tentang konsep relasi antarmanusia yang telah diuraikan di atas, hal ini menunjukkan bahwa kajian relasi antarmanusia yang terdapat dalam nilai-nilai budaya Bugis memiliki relevansi yang kuat dengan usaha pembangunan pemahaman tentang Hak Asasi Manusia atau HAM, khususnya di Indonesia. Kajian di atas dapat dijadikan sebagai sumbangan pemikiran atas persoalan kemanusiaan yang tidak berhenti mendera bangsa ini. Minimal, memberikan pemahaman tentang entitas manusia sebagai makhluk yang berkesadaran, yang memiliki hak-hak mendasar untuk hidup dan menjalani kehidupannya.

\section{DAFTAR PUSTAKA}

Bakker, Anton, 2008, Antropologi Metafisik, Cetakan ke-3, Kanisius, Yogyakarta.

Bertens, K, 2002, Filsafat Barat Kontemporer Inggris-Jerman, Cetakan ke-4, Gramedia Pustaka Utama, Jakarta.

Buber, Martin, 1937, I and Thou, Terj. Ronald Gregor Smith, T and T Clark, Edinburgh.

Dagun, Save M., 1990, Filsafat Eksistensialisme, Rineka Cipta, Jakarta.

Drijarkara, 1989, Filsafat Manusia, Cetakan VIII, Kanisius, Yogyakarta.

Ibrahim, Anwar, 2003, Sulesana, Kumpulan Esai Tentang Demokrasi dan

Kearifan Lokal, Lembaga Penerbitan Universitas Hasanuddin (Lephas), Makassar.

Kaelan, 2005, Metode Penelitian Kualitatif Bidang Filsafat, Paradigma, Yogyakarta. 
Kern, R.A., 1993, I La Galigo, Gadjah Mada University Press, Yogyakarta.

Lathief, Supaat I, 2010, Psikologi Fenomenologi Eksistensialisme, Cetakan ke-2, Pustaka Pujangga, Lamongan.

Marzuki, Mohamad Laica, 1995, Siri': Bagian Kesadaran Hukum Rakyat Bugis-Makassar (Sebuah Telaah Filsafat Hukum), Hasanuddin University Press, Ujung Pandang.

Mattulada, 1995, Latoa, Suatu Lukisan Analitis Terhadap Antropologi Politik Orang Bugis, Cetakan ke-2, Hasanuddin University Press, Makassar.

Pelras, Christian, 2003, "Pendahuluan Siklus La Galigo yang Tak dikenal", dalam Nurhayati Rahman dkk. Ed., La Galigo: Menelusuri Jejak Warisan Sastra Dunia, Pusat Studi La Galigo Universitas Hasanuddin bekerjasama dengan Pemerintah Kabupaten Barru, Makassar.

Toa, Arung Pancana, 1995, I La Galigo (Menurut Naskah NBG 188), Jilid I, Transkripsi dan Terjemahan: Muhammad Salim dan Fachruddin Ambo Enre, KITLV bekerjasama dengan Djambatan, Jakarta.

Toynbee, Arnold, 2004, Sejarah Umat Manusia, Terjemahan: Agung Prihantoro dkk., Pustaka Pelajar, Yogyakarta. 